\title{
Holocene Soil Chronofunctions, Luochuan, Chinese Loess Plateau
}

\author{
Gang Liu, Wennian Xu, Qiong Zhang and Zhenyao Xia \\ China Three Gorges University
}

China

\section{Introduction}

Since soil genesis can hardly be observed directly over decades and centuries, the research of soil chronosequences is the most suitable way to assess quantitative knowledge on soil development (Bockheim, 1980). A soil chronosequence is a quantitative description of how the soils properties in a given area change with time (Vincent, 1994). Soil chronofunctions have been equated with the mathematical expression of chronosequence data, typically utilizing correlations and curve-fitting, or some derived combination. They are useful for studying pedogenesis, relative dating of surfaces and geologic events, and for predicting recovery rates of disturbed soils.

Therefore, numerous studies on chronosequence investigation and chronofunction construction were carried out in the last decades. The classic chronosequences were established on moraines left in the wake of retreating glaciers (Mellor, 1987; Mattews, 1992) and on coastal sand dune systems (Olson, 1958). More recent work on historical chronosequences was investigated on a much wider range of landscapes. In the Luquillo experimental forest, Puerto Rico, a soil chronosequence formed in landslide scars showed that the base saturation index and nutrient cation pools in surface mineral soil increases during primary succession (Zarin and Johnson, 1995). Carreira et al. (1994) evaluated total and mineral $\mathrm{N}$ concentration, net nitrogen mineralization, and nitrification in soils from a burnt patches chronosequence in southeast Spain. The results indicated that an increasing fire frequency in the last few decades was associated with a sharp decrease in surface soil organic matter and total nitrogen concentrations and pools, and with changes in the longterm nitrogen dynamic patterns. In the western Brazilian Amazon Basin state of Rondonia, the net nitrogen mineralization and net nitrification in soil profiles along a tropical forest-topasture chronosequence were examined to investigate possible mechanisms for changes to soil nitrogen sources and transformations that occur as a result of land use (Piccolo et al., 1994). Marine terraces were also suitable for constructing soil chronosequences. Merritts et al. (1991) evaluated six pedogenic properties of soils from chronosequences developed on two flights of unlifted marine terraces in northern California. They found that the soil properties have systematic and time-dependent trends, but each property differs in the rate of change. An example of chronosequences produced on old mining areas is a study on development rate of soil from abandoned phosphate-mined sites on Nauru Island, Central Pacific (Manner and Morrison, 1991). 
Most of the soil chronosequence studies suggest linear, power, exponential or logarithmic changes of soil properties with time. Bockheim (1980) used three linear and non-linear models to construct chronofunctions for fifteen soil properties of thirty-two chronosequences from seven types of parent materials, including till, aeolian sand, alluvium, mine spoil, volcanic ash, raised beach deposits, and mudflow. The singlelogarithmic model showed the best relationship between soil property and time, and more than $85 \%$ of the correlation coefficients were statistically significant. Birkeland (1984) investigated two soil chronosequences from the high country of the South Island of New Zealand to establish chronofunction. Out of a possible twenty one chronofunctions, sixteen were significant at the 0.05 level. Most of the chronofunctions best fit a power model, and the remaining ones are split between linear and exponential models. Chemical and mineralogical characteristics have been determined for a chronosequence of six soil profiles in the western Cairngorms of Scotland (Bain et al., 1993). Exchangeable Ca and Mg decrease with time and base saturation decreases exponentially from $24.6 \%$ in the Ah horizon of the youngest profile to $2.8 \%$ in the comparable horizon of the 10,000 year old profile according to a exponential function. A soil chronosequence in the northern shore of Lake Michigan, USA was investigated (Barrett, 2001). The results indicated that for most forms of extractable $\mathrm{Fe}$ and $\mathrm{Al}$, both linear and log-linear functions adequately describe the changes in property with surface age.

Although linear, power, exponential or logarithmic functions are widely used, they are not always the best option for chronofunctions. Polynomial, hyperbolic, S-shaped, sigmoidal, logistic curve or two separate linear regression lines might improve not only the fit of the chronofunction but also advance our understanding of the pedologic system. Jacobson and Birks (1980) showed a curve in which loss on ignition of A horizons in Canadian soils follows an approximate sigmoidal relationship when plotted against time. For some soil properties, rates of pedogenesis are initially very rapid and then decrease with time, quickly approaching an upper asymptote. This type of data might be easily fitted to hyperbolic functions (Mellor, 1985). Polynomial functions have been successfully used to fit the time and soil properties in soil chronosequences at three sites within the Transantarctic Mountains (Bockheim, 1990). Selection of the appropriate chronofunction model should be both reasonable with respect to fit, as well as theoretically matching the expected temporal trend (Schaetzl et al., 1994).

The building and interpreting of soil chronosequences are hampered by several well-known problems. A major difficulty is dating of soil to establish a precise and reliable time scale. In last decades, many Quaternary dating methods have been improved and developed, including rock stratigraphy, magnetic stratigraphy, archaeology, Ar-Ar laser microprobe dating, Thermal Ionization Mass Spectrometer, Thermol Uminescence dating, Optic Stimulated Luminescence, Electron Spin Resonance, and other isotope dating method, etc. For the loess, two dating methods are always used. One is Thermoluminescence dating which has been applied to loess from the last 100-200 ka. This method is based on several assumptions. During transport, dust is exposed to sunlight, which releases the energy from the crystals and, therefore, resets the clock. After deposition, the loess is radiated by cosmic rays and the primordial radioactive isotopes of $\mathrm{U}$, Th and $\mathrm{K}$ and their daughters. Another important dating method based on radioactive decay is ${ }^{14} \mathrm{C}$ dating. The radiocarbon dating has added precision to existing knowledge regarding the many feet of unconsolidated loessial materials that were deposited alternately during a few thousand years of Holocene 
time in response to environmental fluctuations (Miao, 2005; Muhs et al., 2004). However, due to the relatively short half-life of $5730 \mathrm{yr}$, it is applicable only to the last ca. $40 \mathrm{ka} .{ }^{14} \mathrm{C}$ dating also requires well-defined carbon material of organic origin to guarantee that it reflects the atmospheric ${ }^{14} \mathrm{C} /{ }^{12} \mathrm{C}$ ratio. Only material that has never exchanged with other carbon (e.g., $\mathrm{CaCO}_{3}$ ) present in the loess should be used. Finally, one must be aware that ${ }^{14} \mathrm{C}$ ages have to be calibrated, and at present, the necessary calibration curve covers only the last $13 \mathrm{ka}$.

Another difficulty is holding all soil-forming factors constant except time. In particular, climate is highly unlikely to have held steady, even for short periods. Many studies have been implemented to research paleoclimatic change on Chinese Loess Plateau. Micromorphological investigations on loess-paleosol sequences in Potou section near Luochuan showed that the paleosols with an Ah-C horizon sequence are genetically comparable to the natural Holocene soil and are most probably formed under the environmental conditions of steppe vegetation. The soils with a Bt-Ck horizon sequence the Ah-horizon is always eroded - are forest soils, developed under moister conditions than the Holocene climate (Bronger and Heinkele, 1989). Based on chemical (major and trace element) and isotopic ( $\mathrm{Sr}, \mathrm{Nd}$ ) analyses of the Luochuan loess-paleosol sequence, Gallet et al. (1996) concluded that systematic variations of element abundances and ratios between loess and paleosols can be used as chemical indicators for pedogenetic intensity and so for paleoclimatic change. But the correlation between precipitation and chemistry was not exist in Jahn et al.'s (2001) study in other three sites (Xining, Xifeng, Jixian) on the Chinese Loess Plateau. Maher et al. (1994) proposed a mineral magnetic approach for estimating palaeoprecipitation across the Chinese Loess Plateau. The correlation between pedogenic magnetic susceptibility and contemporary annual rainfall was used to reconstruct rainfall for interglacial and glacial episodes spanning the entire Quaternary. It was concluded that for the last interglacial, the presently dry western sites received up to $60 \%$ more rainfall per year (compared to present), and the presently humid south and east sites up to $30 \%$ more. ${ }^{14} \mathrm{C}$ research of Late Pleistocene and Holocene fossil soils and cultural horizons of archaeological sites also helps reconstructing and modelling natural and climatic changes (Morozova, 1990).

Despite the problems involved in their construction, there is no doubt that soil chronosequences are immensely powerful tools for probing the rate and direction of soil evolution. Indeed, they are the only way of establishing how pedogenesis operates over centuries and longer periods. Well-dated chronosequences are therefore a boon to pedologists. They are also invaluable to geomorphologists, for, once a soil chronosequence is established, it may be used to investigate other landscape processes. After a chronofunction has been obtained from a data set, the y-intercept may also be used to reconstruct the situation at time zero (Schaetzl et al., 1994).

The perfectly preserved Heilu soil could provide important information about environmental evolvement on Chinese Loess Plateau in the Holocene (Tang \& He, 2004; Liu, 2009). Heilu soils are principal soil components on gently rolling or undulating land surfaces, of the Loess Plateau where past erosion has been limited. Several studies on chronosequence of Heilu soil profile were carried out, but the chronofunctions were seldom descibed (Hu, 1994; Chen et al., 1998; Tang \& He, 2002). The aim of this study was to characterize physical-chemical properties in a well-constrained and dated Holocene Heilu 
soil profile, establish soil chronofunctions, in order to improve the understanding of soil formation and development with time, to provide theoretical basis for prediction of soil recover and data for modeling soil genesis (Finke \& Hutson, 2008).

\section{Materials and methods}

\subsection{Study area}

The Loess Plateau in northwest China covers an area of 530,000 $\mathrm{km}^{2}$, larger than Spain and almost as large as France; the loess cover largely ranges in thickness from 30 to $80 \mathrm{~m}$. The loessial soils are characterized by its yellowish colors, absence of bedings, silty texture, looseness, macroporosity and collapsibility when saturated. The Loess Plateau is conveniently divided into three zones: sandy loess in the northern part, typical loess in the middle, and clayey loess in the south (Liu, 2009). The soil chronosequence was located in Luochuan (N35 $\left.42.561^{\prime}, \mathrm{E} 109^{\circ} 23.952^{\prime}\right)$, where the landform is a loess tableland, in the middle of Chinese Loess Plateau (Figure 1). The climatic conditions of this area are characterized by warm and semi-humid continental monsoon climate. Mean annual precipitation in Luochuan is about $622 \mathrm{~mm}$, concentrated in the summer (July to September). Conversely, the climate is cold and dry in winter, with low rainfall. The mean annual temperature range is $9.2^{\circ} \mathrm{C}$. The present-day vegetation in the study area is dominated by grasses and shrubs (Poaceae, Leguminosae, Labiatae, Rhamnaceae, and Compositae).

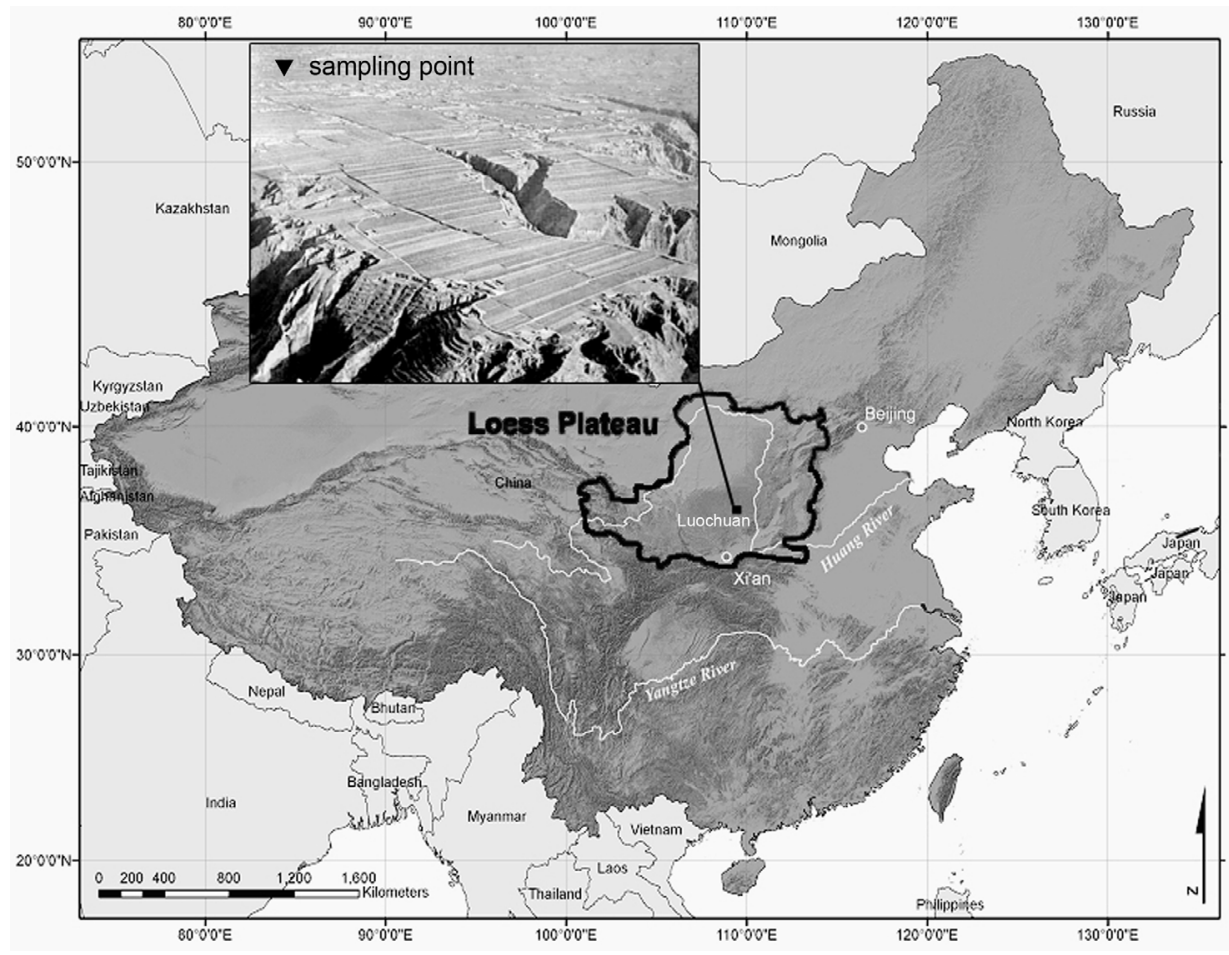

Fig. 1. Location of the soil chronosequence and relief of the study area at Luochuan, China. 


\subsection{Field work and laboratory analyses}

The soil layers were sampled from the face of a hand-dug pit, approximately $50 \mathrm{~cm} \times 200 \mathrm{~cm}$ at the top and about $200 \mathrm{~cm}$ deep. Standard morphological description was made and the samples were uniformly scraped from the face of pit at $10-\mathrm{cm}$ intervals. The interval was occasionally modified to avoid sampling across a horizon boundary.

In the laboratory, after air-drying and picking out visible roots and stone fragments, samples were passed through a 2-mm sieve. The amounts of organic carbon and carbonatecarbon were determined by a carbon analyzer with stepped heating routine (LECO RC 412), successively measuring both carbon fractions in two replicates. The soil samples were treated with $\mathrm{H}_{2} \mathrm{O}_{2}$ and $\mathrm{HCl}$ to remove organic matter, prepared with $\mathrm{Na}_{4} \mathrm{P}_{2} \mathrm{O}_{7}$ and treated with ultrasound for 3 min before analysis. A standard procedure was used for operating the Malvern Mastersizer 2000. The $\mathrm{pH}$ was determined in deionised water using a soil:water ratio of 1:2.5. The total elements, including $\mathrm{Mn}, \mathrm{Fe}, \mathrm{K}, \mathrm{Na}, \mathrm{Ca}, \mathrm{Mg}$, and $\mathrm{Zr}$ were determined by X-ray fluorescence analysis (XRF) of fused discs. $\mathrm{P}$ was extracted sequentially by the procedure developed by Hedley et al. (1982) and measured by an absorption spectrophotometer.

For all soil samples, the extraction of humin and radiocarbon dating were carried out at the AMS ${ }^{14} \mathrm{C}$ laboratory of Institute of Earth Environment, Chinese Academy of Sciences, China. All soil samples were oven dried $\left(60^{\circ} \mathrm{C}\right)$ to constant weight, then ground and sieved. In order to extract humic acids and date the humin fraction only, samples are commonly treated with acid and alkali (Mook and Streurman, 1983). All pre-treated samples were combusted by sealing the sample with $\mathrm{CuO}$ wire in an evacuated quartz tube, then placing the tube in a $950^{\circ} \mathrm{C}$ oven for 2 hours. The resulting $\mathrm{CO}_{2}$ was purified and reduced to graphite targets for AMS using the apparatus and methods described in Vogel et al. (1987). The calibration of the ${ }^{14} \mathrm{C}$ age used the methods of Bronk Ramsey (2001) and Reimer et al. (2004).

\subsection{Data evaluation}

The results of the laboratory analyses were evaluated by analyzing soil depth functions and chronofunctions. In this study, three kinds of usually considered functions (Bockheim 1980, Schaetzl et al. 1994) including linear $(Y=a+b X)$, logarithmic $(Y=a+b \ln X)$, and third order polynomial $\left(Y=a+b X+c X^{2}+d X^{3}\right)$ were used to fit the relationships between soil properties $(Y)$ and soil ages $(X)$. We selected the appropriate chronofunction model by the coefficient of determination $\left(\mathrm{r}^{2}\right)$, as well as theoretically matching the expected temporal trend.

\section{Results and discussion}

\subsection{Soil morphology and classification}

Zhu (1983) proposed the name Heilu for a kind of soil which differs appreciably from the regional light "Shestnut" soils and "Kastanozems". Heilu soils have brownish dark grey humus horizons at the surface that are usually 60-100 cm thick. Below the humus-rich horizons, deeper horizon is light gray-brown in color. Predominant textures in the profile are light to medium loam although the humus-rich A horizon showed from $8.5 \%$ to $22 \%$ clay. Illuvial Carbonates precipitate of deeper horizon appear chiefly in pseudomycelial and 
powdery forms. Small numbers of carbonate microconcretions are also present with depth, both in the soil and the underlying loess material. According to all morphological traits, the sampled pedon was classified as Heilu type soil in this study (Table 1). The ages of the Heilu soil profile was ranging from $841 \pm 32$ to $12816 \pm 40$ radiocarbon years BP (Figure 2). Figure 2 illustrated good linear relationships between soil age and depth with a high coefficient of determination $\left(R^{2}\right)$. The slope of function showed average loess formation rate of profile in the Holocene was $0.0174 \mathrm{~cm} / \mathrm{a}$.

\begin{tabular}{|c|c|l|}
\hline Horizon & Depth $(\mathrm{cm})$ & \multicolumn{1}{c|}{ Description } \\
\hline Ap & $0 \sim 21$ & $\begin{array}{l}\text { Light grayish brown, 10YR7/6 (moist), clay loam, weak } \\
\text { medium granular structure, slightly hard (dry), abundant } \\
\text { roots, some carbonate pseudomycelia in small spots, gradual } \\
\text { smooth boundary. }\end{array}$ \\
\hline Ah & $21 \sim 80$ & $\begin{array}{l}\text { Darkish brown, 7.5YR3/3 (moist), clay loam, fine subangular } \\
\text { blocky structure, hard (dry), abundant roots, some } \\
\text { pseudomycelia in root channels, a few krotowinas filled with } \\
\text { C-material, smooth boundary. }\end{array}$ \\
\hline AB & $80 \sim 100$ & $\begin{array}{l}\text { Color heterogeneity, darkish brown blocks in pale brown soils, } \\
\text { clay loam, fine subangular blocks break to granules, slightly hard } \\
\text { (dry), few roots, plenty of pseudomyceli, smooth boundary. }\end{array}$ \\
\hline $\mathrm{Bk}$ & $100 \sim 129$ & $\begin{array}{l}\text { Very pale brown, 7.5YR5/3 (moist), clay loam, massive, hard } \\
\text { (dry), some very fine pores, few pseudomycelia, some lime } \\
\text { nodules of 0.5-1 cm in diameter, few roots, clear boundary. }\end{array}$ \\
\hline $\mathrm{C}$ & $129 \sim 200$ & $\begin{array}{l}\text { Yellowish brown, 10YR8/4 (moist), clay loam, blocks break to } \\
\text { granules, slightly hard (dry), few roots. }\end{array}$ \\
\hline
\end{tabular}

Table 1. Soil horizon designations

Soil age (a)

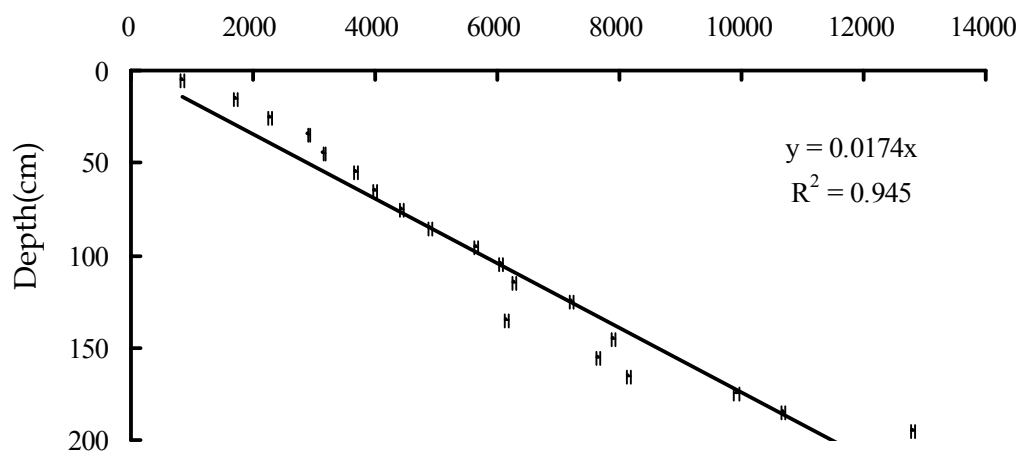

Fig. 2. The linear relationship between radiocarbon age and depth in the profiles. $x$ and $y$ in the equations is soil age and depth, $\mathrm{R}^{2}$ is coefficient of determination. Bars represent \pm error of measurement. 
The most noticeable pedogenic processes in the field are organic carbon accumulation and calcium carbonate leaching in the upper centimeters of the soils, and illuviation further down the profile a few decimeters below. The calcium carbonate accumulations are very intensive in the Holocene soils.

\subsection{Particle size distribution}

The particle size distribution clearly reflected the predominance of silt $(0.002-0.02 \mathrm{~mm})$ and clay $(<0.002 \mathrm{~mm})$ (by International Particle Size Classification System) in the Ah horizon, where the soil age was about between 1500 and 4200 a B.P., indicating that clay formation was mainly restricted to the upper layer. Fining of upper horizons with increasing age has often been reported in chronosequences (Barrett, 2001).

Logarithmic functions for different particle classification were not statistically significant (Table 2). The corresponding linear functions were statistically significant except silt. However, all of them were rejected due to relatively low coefficients of determination. Third order polynomial models for three particle classifications were statistically very significant, and with higher coefficients of determination.

\begin{tabular}{|c|c|c|c|c|c|c|}
\hline Equations & Classification & $A$ & $b$ & $c$ & $d$ & $\mathrm{r}^{2}$ \\
\hline \multirow{3}{*}{$Y=a+b X$} & Clay $^{*}$ & 17.39 & $-2.00 \times 10^{-4}$ & & & 0.26 \\
\cline { 2 - 7 } & Silt & 42.05 & $-4.00 \times 10^{-4}$ & & & 0.16 \\
\cline { 2 - 7 } & Sand & 40.57 & $6.00 \times 10^{-4}$ & & & 0.20 \\
\hline \multirow{3}{*}{$Y=a+b \ln X$} & Clay & 21.20 & -0.62 & & & 0.07 \\
\cline { 2 - 7 } & Silt & 42.86 & -0.35 & & & 0.01 \\
\cline { 2 - 7 } & Sand & 35.95 & 0.97 & & & 0.02 \\
\hline \multirow{3}{*}{$Y=a+b X+c X^{2}+d X^{3}$} & Clay $^{* *}$ & 12.88 & $24.00 \times 10^{-4}$ & $-4.00 \times 10^{-7}$ & $2.00 \times 10^{-11}$ & 0.59 \\
\cline { 2 - 7 } & Silt** & 31.38 & $53.00 \times 10^{-4}$ & $-8.00 \times 10^{-7}$ & $3.00 \times 10^{-11}$ & 0.79 \\
\cline { 2 - 7 } & Sand & 55.74 & $77.00 \times 10^{-4}$ & $1.00 \times 10^{-6}$ & $-5.00 \times 10^{-11}$ & 0.75 \\
\hline${ }^{*} \mathrm{a}<0.05 ;{ }^{* *} \mathrm{a}<0.01$ & \multicolumn{7}{|l}{} & & \\
\hline
\end{tabular}

Table 2. Regression equations for different particle-size classification

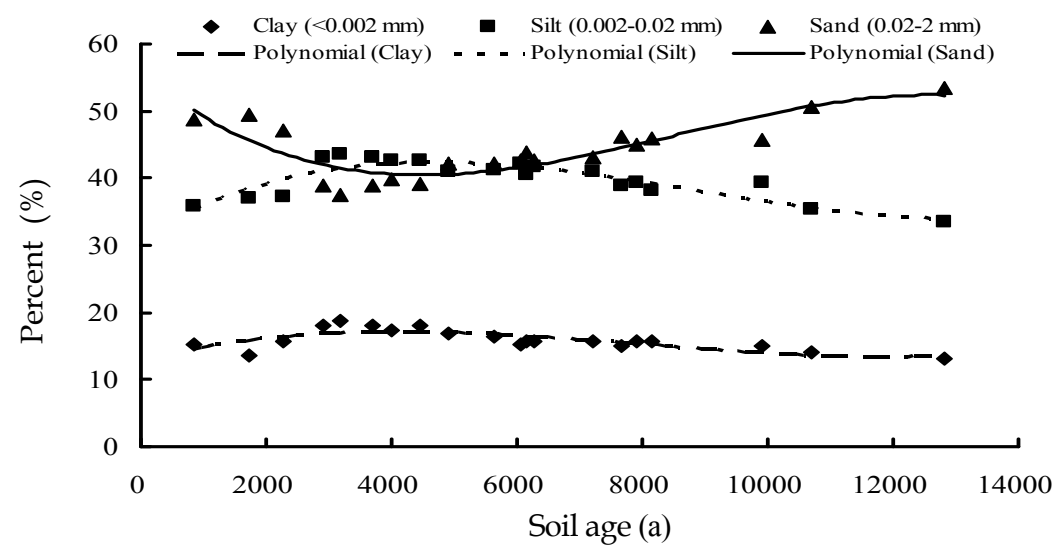

Fig. 3. Different particle-size classification as a function of soil age and regression curves of three order polynomial function 
Our results contrast with Bockheim (1980) and Merritts et al. (1991) who found that logarithmic functions could adequately describe the relationship between clay and soil age, and Barrett (2001) who reported that changing silt content with time could be best fitted by linear models. The difference may be attributed to appearance of a humus horizon (Ah) which had greeter contents of clay and silt, and less sand than Ap and AB horizons (Figure 3). The clay in Ah horizon of the Heilu soil was derived from the in situ weathering of sandsized particles, but not from illuviation from upper Ap horizon. The dry climate in this area conditioned a lower weathering degree and clay formation in the Ah horizon.

\subsection{Organic carbon, calcium carbonate and $\mathrm{pH}$}

Linear, logarithmic and third order polynomial functions for organic carbon were statistically very significant and with very high coefficients of determination (around 0.8) (Table 3). But the intercepts of linear and third order polynomial functions, 0.57 and 0.6 , were lower than 0.66 in surface layer. Theoretically, the organic carbon content in surface soil should be higher than any underlying soil layer (Chen, 2005). Data from Tang \& He (2004) studies on Heilu soil agreed with our results from in Luochuan. Therefore, the intercept of logarithmic function, 1.68, was suitable, and it was the best fitting chronofunction for organic carbon content (Figure 3).

\begin{tabular}{|c|c|c|c|c|c|c|}
\hline Equations & Property & $a$ & $b$ & $C$ & $d$ & $\mathrm{r}^{2}$ \\
\hline \multirow{3}{*}{$Y=a+b X$} & Organic carbon $^{* *}$ & 0.57 & $-3.00 \times 10^{-5}$ & & & 0.79 \\
\cline { 2 - 7 } & Calcium carbonate $^{* *}$ & -2.87 & $16.00 \times 10^{-4}$ & & & 0.74 \\
\cline { 2 - 7 } & $\mathrm{pH}^{* *}$ & 8.10 & $2.00 \times 10^{-5}$ & & & 0.80 \\
\hline \multirow{3}{*}{$Y=a+b \ln X$} & Organic carbon** $^{* *}$ & 1.68 & -0.15 & & & 0.79 \\
\cline { 2 - 7 } & Calcium carbonate $^{* *}$ & -51.39 & 6.83 & & & 0.59 \\
\cline { 2 - 7 } & $\mathrm{pH}^{* *}$ & 7.48 & 0.09 & & & 0.90 \\
\hline \multirow{3}{*}{$Y=a+b X+c X^{2}+d X^{3}$} & Organic carbon $^{* *}$ & 0.60 & $-5.00 \times 10^{-5}$ & $8.00 \times 10^{-10}$ & $2.00 \times 10^{-14}$ & 0.81 \\
\cline { 2 - 7 } & Calcium carbonate & 4.78 & $-41.00 \times 10^{-4}$ & $1.00 \times 10^{-6}$ & $-5.00 \times 10^{-11}$ & 0.85 \\
\cline { 2 - 7 } & $\mathrm{pH}^{* *}$ & 8.02 & $6.00 \times 10^{-5}$ & $-7.00 \times 10^{-9}$ & $3.00 \times 10^{-13}$ & 0.88 \\
\hline \multirow{2}{*}{$\mathrm{C}<0.01$}
\end{tabular}

Table 3. Regression equations for organic carbon, calcium carbonate and $\mathrm{pH}$

Though both linear and logarithmic functions for calcium carbonate were statistically very significant and have relatively high $\mathrm{r}^{2}(0.74$ and 0.59$)$. Their intercepts were negative $(-2.87$ and -51.39) (Table 3). Hence, they can not describe the relationship between calcium carbonate content and soil age. However, this relationship could be best fitted by a third order polynomial function which has high $\mathrm{r}^{2}$ value (0.85). This chronofunction showed redistribution of calcium carbonate, dissolution in the upper horizon, followed by reprecipitation and enrichment in the lower horizon, and the lowest value was observed in Ah horizon (Figure 4). This trend agrees well with the results of Tang \& He (2004) and Zhao et al. (2006) for Heilu soil.

All of three functions for $\mathrm{pH}$ were statistically very significant and had high $\mathrm{r}^{2}$ values (Table $3)$, indicating that theory must be utilized and incorporated when selecting equations. Huang \& Gong (2001) and Jia et al. (2004) observed that $\mathrm{pH}$ values increased with soil age rapidly due to alkalinization which was caused by leaching at initial stage of soil formation, and the increase in lower horizons was slower. The logarithmic function for $\mathrm{pH}$ could show this trend best (Figure 4). 

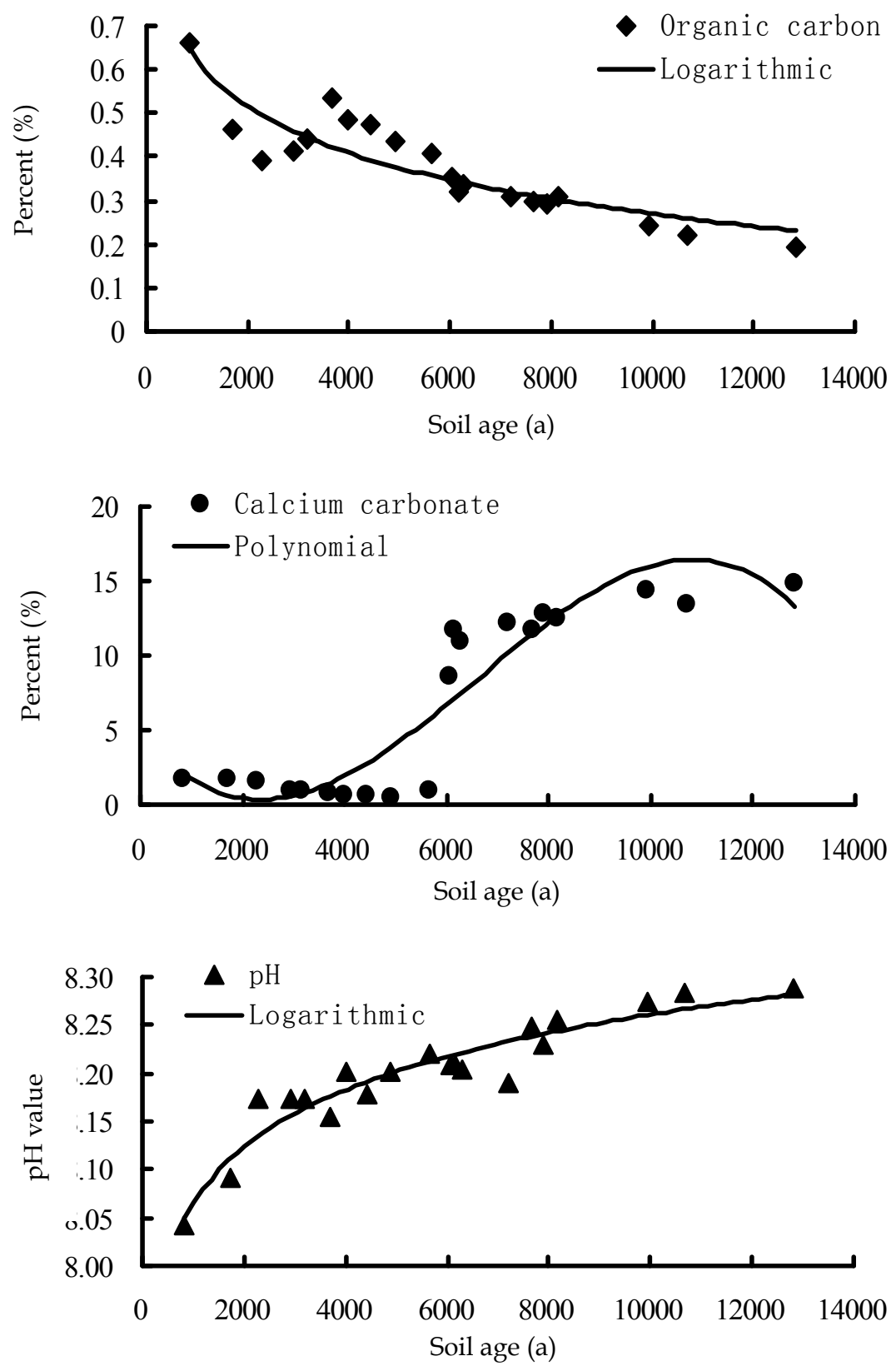

Fig. 4. The content of soil organic carbon, calcium carbonate, and $\mathrm{pH}$ as a function of soil age and regression curves 


\subsection{Mobility of elements in soil}

In many studies, of the relations between selected mobile elements and $\mathrm{Ti}$ or $\mathrm{Zr}$ were used to identify enrichment and depletion of elements with time (Egli \& Fitze, 2000). Since Ti can also be mobilized, $\mathrm{Zr}$ is considered more suitable for this purpose (Langley-Turnbaugh \& Bockheim, 1998; Sauer et al., 2007).

Logarithmic and third order polynomial functions for $\mathrm{Mn} / \mathrm{Zr}, \mathrm{Fe} / \mathrm{Zr}$ and $\mathrm{K} / \mathrm{Zr}$ were statistically very significant (Table 4 ). They showed similar trends, in which ratio increased sharply before about 3000 a B.P., being constant in the older soils (Figure 5). It indicated that mobility or removal of $\mathrm{Mn}, \mathrm{Fe}$ and $\mathrm{K}$ with time was greater in the upper centimeters, whereas depletion or enrichment were negligible in the older lower layers. The third order polynomial functions were more fitted than logarithmic functions in this study, due to higher $\mathrm{r}^{2}$ (Table 4). On the other hand, the relationships between $\mathrm{Mn}, \mathrm{Fe}, \mathrm{K}$ and time were best fitted by linear and logarithmic functions in studies elsewhere (Lichter, 1998; Egli \& Fitze, 2000; Sauer et al., 2007), probably attributed to different pedological contexts. These results agree well with Tang \& He (2004).

\begin{tabular}{|c|c|c|c|c|c|c|}
\hline Equations & Ratio & $a$ & $b$ & $c$ & $d$ & $\mathrm{r}^{2}$ \\
\hline \multirow{7}{*}{$Y=a+b X$} & $\mathrm{Mn} / \mathrm{Zr}^{*}$ & 217.22 & $3.00 \times 10^{-3}$ & & & 0.22 \\
\hline & $\mathrm{Fe} / \mathrm{Zr}^{* *}$ & 10362.00 & 0.22 & & & 0.44 \\
\hline & $\mathrm{K} / \mathrm{Zr}^{* *}$ & 6175.20 & 0.15 & & & 0.68 \\
\hline & $\mathrm{Na} / \mathrm{Zr}^{* *}$ & 4092.90 & 0.10 & & & 0.62 \\
\hline & $\mathrm{Ca} / \mathrm{Zr}^{* *}$ & -4439.10 & 2.18 & & & 0.77 \\
\hline & $\mathrm{Mg} / \mathrm{Zr}^{* *}$ & 3527.00 & 0.27 & & & 0.92 \\
\hline & $\mathrm{P} / \mathrm{Zr}^{* *}$ & 141.63 & 0.01 & & & 0.68 \\
\hline \multirow{7}{*}{$Y=a+b \ln X$} & $\mathrm{Mn} / \mathrm{Zr}^{* *}$ & 61.71 & 20.39 & & & 0.46 \\
\hline & $\mathrm{Fe} / \mathrm{Zr}^{* *}$ & 809.08 & 1276.10 & & & 0.67 \\
\hline & $\mathrm{K} / \mathrm{Zr}^{* *}$ & 660.09 & 751.88 & & & 0.78 \\
\hline & $\mathrm{Na} / \mathrm{Zr}^{* *}$ & 1358.60 & 392.23 & & & 0.41 \\
\hline & $\mathrm{Ca} / \mathrm{Zr}^{* *}$ & -68638.00 & 9049.10 & & & 0.61 \\
\hline & $\mathrm{Mg} / \mathrm{Zr}^{* *}$ & -5071.10 & 1197.70 & & & 0.82 \\
\hline & $\mathrm{P} / \mathrm{Zr}^{* *}$ & -181.56 & 44.99 & & & 0.61 \\
\hline \multirow{7}{*}{$Y=a+b X+c X^{2}+d X^{3}$} & $\mathrm{Mn} / \mathrm{Zr}^{* *}$ & 153.32 & 0.04 & $-5.00 \times 10^{-6}$ & $2.00 \times 10^{-10}$ & 0.69 \\
\hline & $\mathrm{Fe} / \mathrm{Zr}^{* *}$ & 7664.10 & 1.65 & $-2.00 \times 10^{-4}$ & $7.00 \times 10^{-9}$ & 0.78 \\
\hline & $\mathrm{K} / \mathrm{Zr}^{* *}$ & 5455.40 & 0.48 & $-4.00 \times 10^{-5}$ & $9.00 \times 10-10$ & 0.81 \\
\hline & $\mathrm{Na} / \mathrm{Zr}^{* *}$ & 4894.30 & -0.44 & $9.00 \times 10^{-5}$ & $-4.00 \times 10^{-9}$ & 0.79 \\
\hline & $\mathrm{Ca} / \mathrm{Zr}^{* *}$ & 5832.50 & -5.34 & $14.00 \times 10^{-4}$ & $-7.00 \times 10^{-8}$ & 0.88 \\
\hline & $\mathrm{Mg} / \mathrm{Zr}^{* *}$ & 3811.10 & -0.04 & $7.00 \times 10^{-5}$ & $-4.00 \times 10^{-9}$ & 0.96 \\
\hline & $\mathrm{P} / \mathrm{Zr}^{* *}$ & 165.90 & 0.02 & $6.00 \times 10^{-6}$ & $-3.00 \times 10^{-10}$ & 0.84 \\
\hline
\end{tabular}

Table 4. Regression equations for the ratio of different soil element and zirconium

The ratios between the mobile elements $\mathrm{Ca}, \mathrm{P}, \mathrm{Na}$ and "stable" $\mathrm{Zr}$ clearly indicated their removal in upper layers and enrichment downward, with a minimum in the Ah horizon (Figure 6). The steeper slope indicates a faster migration of Ca compared with either $\mathrm{P}$ or $\mathrm{Na}$. Figure 6. The ratio of $\mathrm{Ca} / \mathrm{Zr}, \mathrm{Na} / \mathrm{Zr}$, and $\mathrm{P} / \mathrm{Zr}$ as a function of soil age and regression curves. However, literature reported that correlations between $\mathrm{Ca}, \mathrm{P}, \mathrm{Na}$ removed with time 
are described by linear and logarithmic models for non-calcareous soils (Lichter, 1998; Egli \& Fitze, 2000; Sauer et al., 2007).
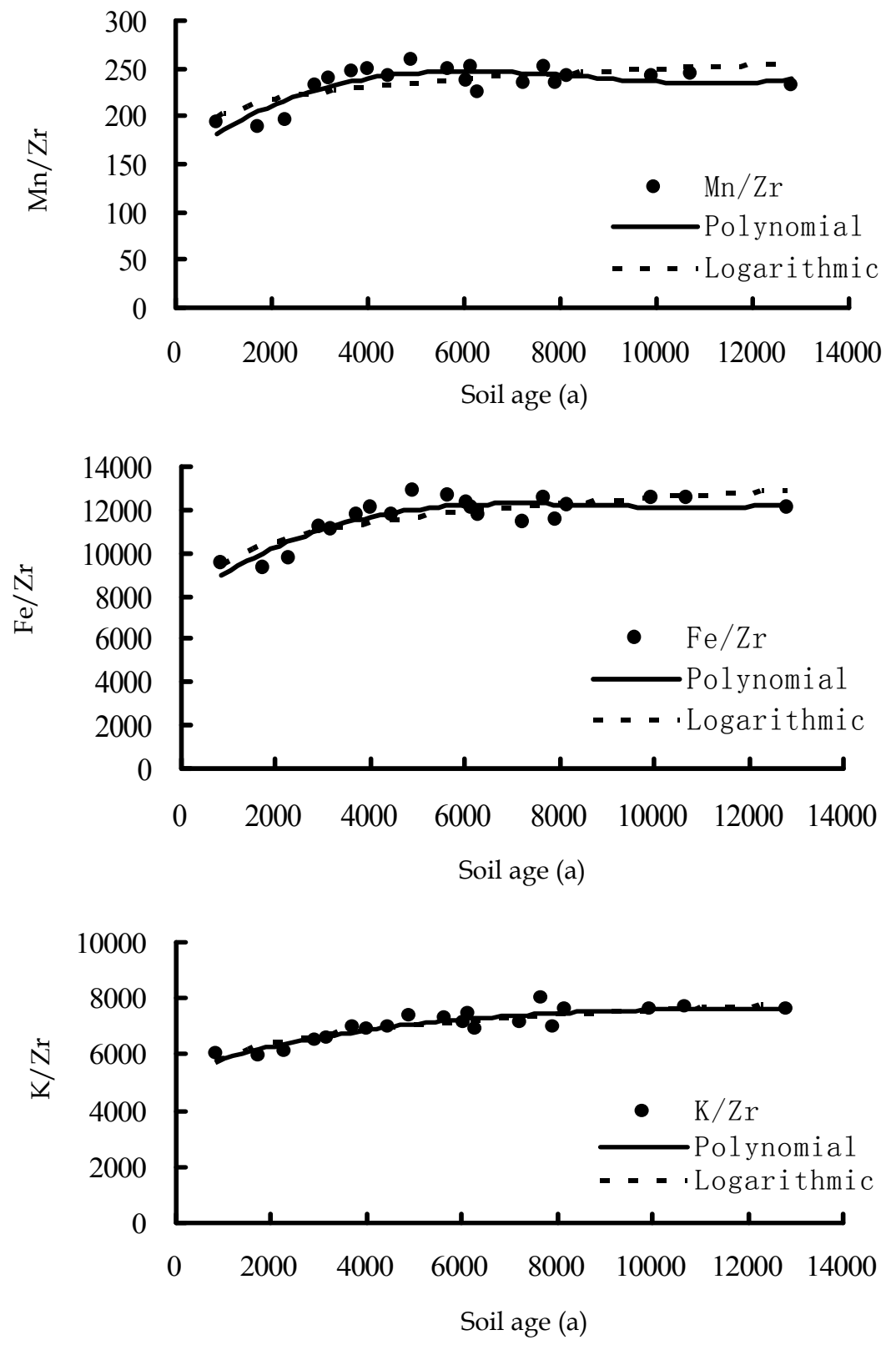

Fig. 5. The ratio of $\mathrm{Mn} / \mathrm{Zr}, \mathrm{Fe} / \mathrm{Zr}$, and $\mathrm{K} / \mathrm{Zr}$ as a function of soil age and regression curves 

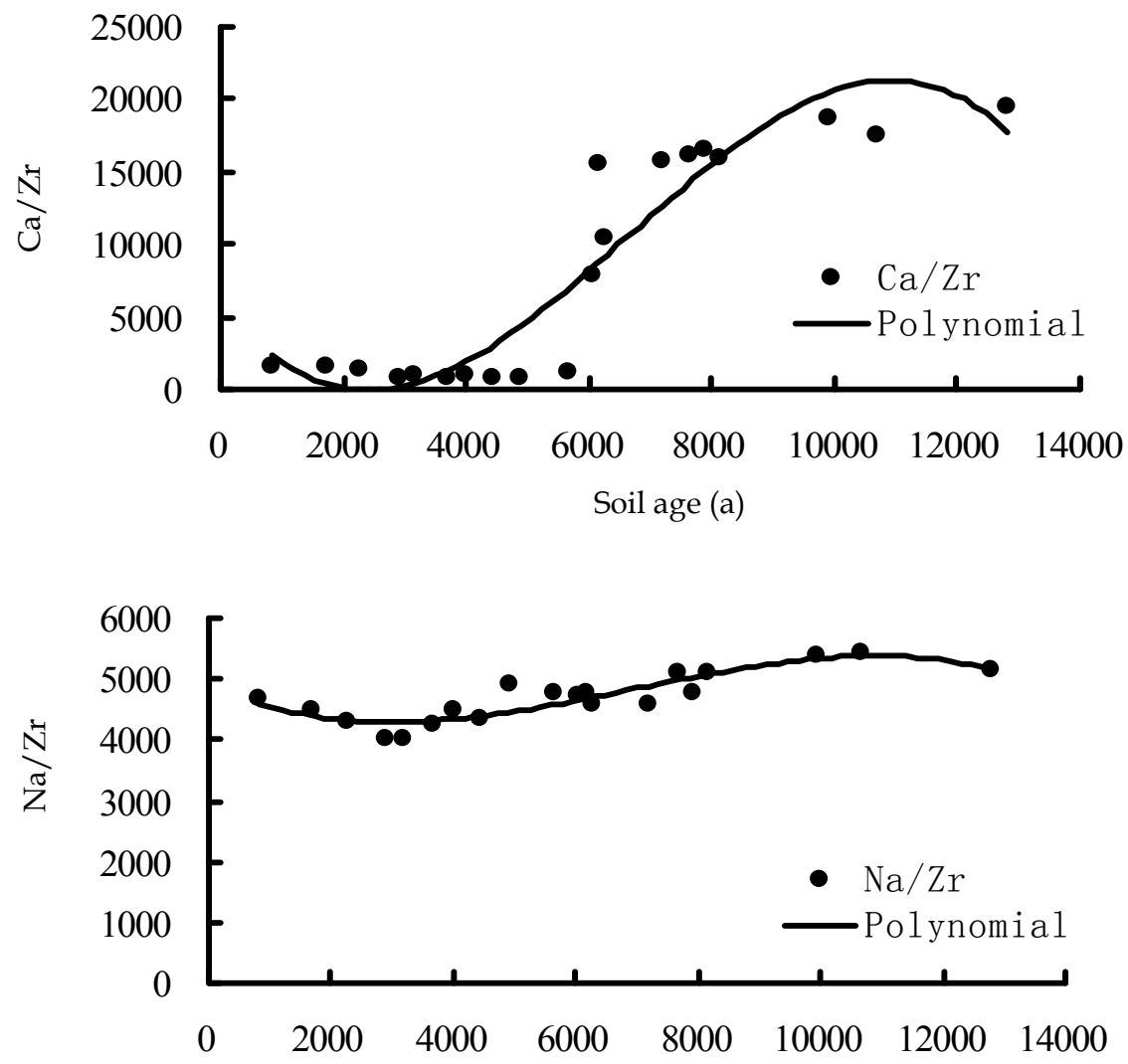

Soil age (a)

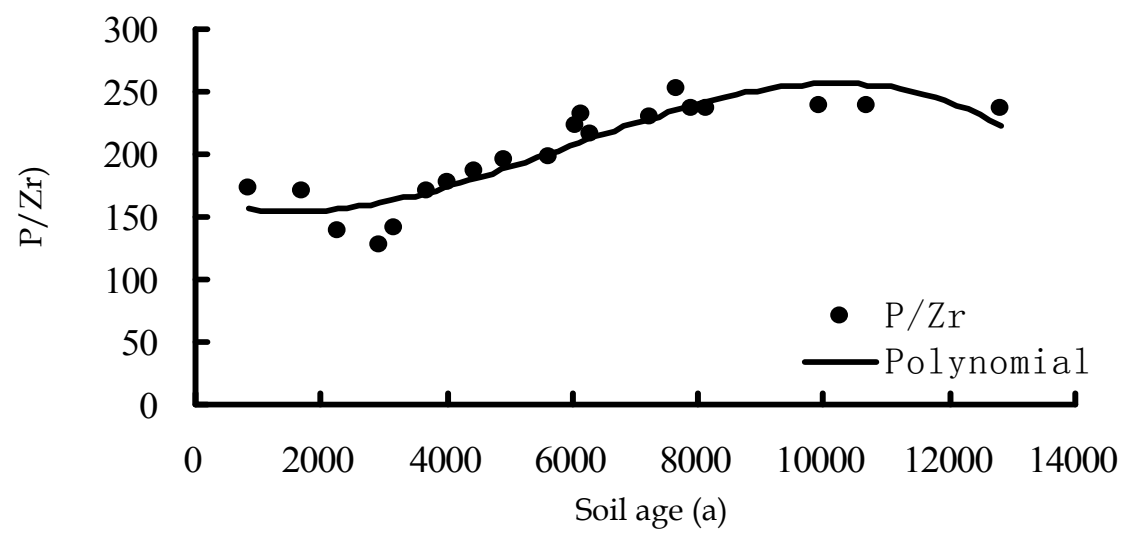

Fig. 6. The ratio of $\mathrm{Ca} / \mathrm{Zr}, \mathrm{Na} / \mathrm{Zr}$, and $\mathrm{P} / \mathrm{Zr}$ as a function of soil age and regression curves 


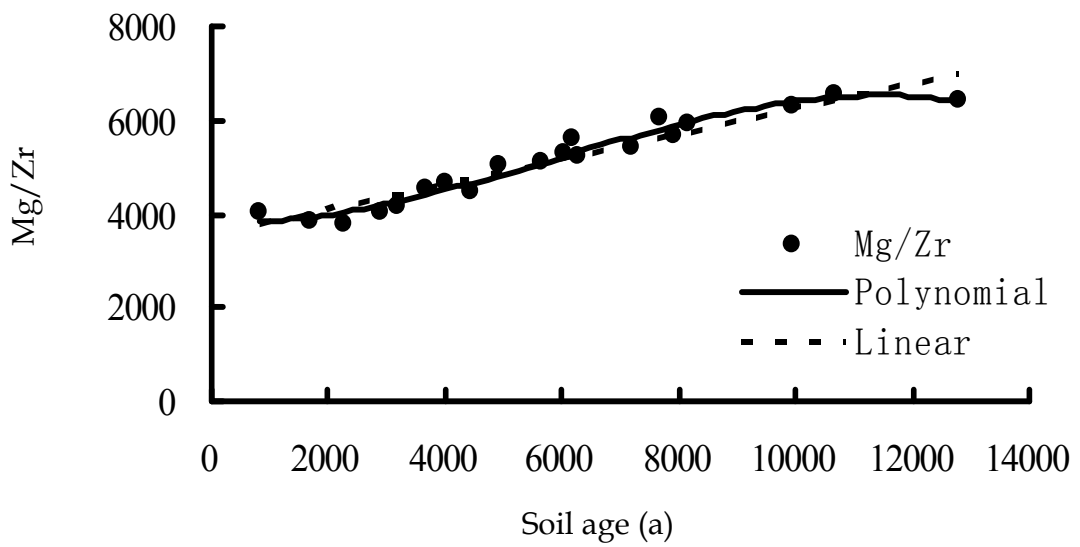

Fig. 7. The ratio of $\mathrm{Mg} / \mathrm{Zr}$ as a function of soil age and regression curves

Linear and third order polynomial functions for $\mathrm{Mg} / \mathrm{Zr}$ were statistically very significant, and had high $\mathrm{r}^{2}$ (0.92 and 0.96) (Table 5). However, they showed different trends (Figure 7). The linear function indicated a constant increasing, implying a constant depletion during the Holocene, a feature difficult to accept given that the Heilu soil formed under varying climatic condition (Tang \& He, 2004). In contrast, the third order polynomial function showed a rapid removal in the surface soil, followed by a slower depletion in older soils, remaining constant in the parent material. But linear and logarithmic increases for different soil chronosequences have been described in many studies elsewhere (Lichter, 1998; Egli \& Fitze, 2000).

\section{Conclusions}

We studied soil chronofunctions, based on soil properties and ${ }^{14} \mathrm{C}$ ages in Holocene of a typical soil (Heilu) profile developed from loess in Luochuan. Linear, logarithmic, and third order polynomial functions were used to fit the relationships between soil properties and soil ages. The results indicated that the third order polynomial function was the best choice to fit the relationships between clay, silt, sand and soil ages. The trend line confirmed the presence of a humic A horizon in the profile, with higher clay and silt contents attributed to local clay formation in the relative warm and humid period between 1500 and 4200 a B.P. (Tang \& He, 2004). The logarithmic functions explained best the variations of soil organic carbon and $\mathrm{pH}$ with time. The $\mathrm{pH}$ values increased with time and depth, with lower increases in older soils. The variation of $\mathrm{CaCO}_{3}$ content, and ratios between $\mathrm{Mn} / \mathrm{Zr}, \mathrm{Fe} / \mathrm{Zr}$, $\mathrm{K} / \mathrm{Zr}, \mathrm{Mg} / \mathrm{Zr}, \mathrm{Ca} / \mathrm{Zr}, \mathrm{P} / \mathrm{Zr}$, and $\mathrm{Na} / \mathrm{Zr}$ with soil age were better described by the use of three order polynomial functions. The results indicated that mobility of $\mathrm{Mn}, \mathrm{Fe}$ and $\mathrm{K}$ was greater in the upper layers with depletion and enrichment of them was very weak in the lower soils. The trend of chronofunction for $\mathrm{Mg}$ showed that a quickly leaching in surface soil, then a slower depletion in older soils, and a constant in parent material. The ratios between $\mathrm{Ca}, \mathrm{P}, \mathrm{Na}$ and $\mathrm{Zr}$ clearly indicated leaching of them in upper centimeters and enrichment in lower soils, also the minimum in Ah horizon. 


\section{Acknowledgment}

This research was jointly supported by the China Postdoctoral Science Foundation (Grant No. 20110491162), Foundation of Hubei Provincial Department of Education (Grant No. Q20111207, XD20100595), Open Research Fund Program of the State Key Laboratory of Soil Erosion and Dryland Farming on the Loess Plateau (Grant No. 10501-266), and Foundation of China Three Gorges University (Grant No. KJ2009B033, KJ2009A002).

\section{References}

Bain, D. C. ; Mellor, A. ; Robertson-Rintoul, M. S. E. \& Buckland, S. T. (1993). Variations in weathering processes and rates with time in a chronosequence of soils from Glen Feshie, Scotland. Geoderma, Vol. 57, No. 3, pp. 275-293, ISSN 0016-7061

Barrett, L. R. (2001). A strand plain soil development sequence in Northern Michigan, USA. Catena, Vol. 44, No. 3, pp. 163-186, ISSN 0341-8162

Birkeland, P. W. (1984). Holocene soil chronofunctions, Southern Alps, New Zealand. Geoderma, Vol. 34, No. 2, pp. 115-134, ISSN 0016-0761

Bockheim, J. G. (1980) Solution and use of chronofunctions in studying soil development. Geoderma, vol. 24, No.1, pp. 71-84, ISSN 0016-0761

Bockheim, J. G. (1990). Soil development rates in the Transantarctic Mountains. Geoderma, Vol. 47, No. 1-2, pp. 59 -77, ISSN 0016-0761

Bronger, A. \& Heinkele, TH. (1989). Micromorphology and genesis of paleosols in the Luochuan loess section, China : Pedostratigraphic and environmental implications. Geoderma, Vol. 45, No. 2, pp. 123-143, ISSN 0016-0761

Bronk Ramsey, C. (2001). Development of the radiocarbon calibration program. Radiocarbon, Vol. 43, No. 2A, pp. 355-363, ISSN 0033-8222

Carreira, J. A.; Niell, F. X. \& Lajtha, K. (1994). Soil nitrogen availability and nitrification in Mediterranean shrublands of varying fire history and successional stage. Biogeochemistry Vol. 26, No. 3, pp. 189-209, ISSN 0168-2563

Chen, Q. Q.; Shen, C. D.; Sun, Y. M.; Peng, S. L.; Yi, W. X.; Li, Z. A. \& Jiang, M. T. (2005). Mechanism of distribution of soil organic matter with depth due to evolution of soil profiles at the Dinghushan Biosphere Reserve. Acta Pedologica Sinica, Vol. 42, No. 1, pp. 1-8, ISSN 0564-3929

Chen, X. Y.; Wu, L. G.; Li, S. L. \& Luo, L. P. (1998). Genesis and evolution of Heilu soils in the south of Wumeng in the Holocene. Chinese Journal of Soil Science, Vol. 29, No. 6, pp. 241-244, ISSN 0564-3945

Egli, M. \& Fitze, P. (2000). Formulation of pedologic mass balance based on immobile elements: a revision. Soil Science, Vol. 165, No. 5, pp. 437-443, ISSN 0038-075X

Finke, P. A. \& Hutson, J. L. (2008). Modelling soil genesis in calcareous loess. Geoderma, Vol. 145, No. 3-4, pp. 462-479, ISSN 0016-7061

Gallet, S.; Jahn, B. M. \& Torii, M. (1996). Geochemical characterization of the Luochuan loess-paleosol sequence, China, and paleoclimatic implications. Chemical Geology, Vol. 133, No. 1-4, pp. 67-88, ISSN 0009-2541

Hedley, M. J.; Stewart, J. W. B. \& Chauhan, B. S. (1982). Changes in inorganic and organic soil phosphorus fractions induced by cultivation practices and by laboratory incubations. Soil Science Society of America Journal, Vol. 46, No.5, pp. 970-976, ISSN 0361-5995 
Hu, S. X. (1994). Genesis and evolution of heilu soils in the middle and east of Gansu Province. Acta Pedologica Sinica, Vol. 31, No. 3, pp. 295-304, ISSN 0564-3929

Huang, C. M. \& Gong, Z. T. (2000). Quantitative studies on development of tropical soils: a case study in northern Hainan Island. Scientia Geographica Sinica, Vol. 20, No. 4, pp. 337-342, ISSN 1000-0690

Jacobson, G. L. \& Birks, H. J. B. (1980). Soil development on recent end moraines of the Klutlan Glacier, Yukon Territory, Canada. Quaternary Research, Vol. 14, No. 1, pp. 87- 100, ISSN 0033-5894

Jahn, B. M.; Gallet, S. \& Han, J. (2001). Geochemistry of the Xining, Xifeng and Jixian sections, Loess Plateau of China: eolian dust provenance and paleosol evolution during the last $140 \mathrm{ka}$. Chemical Geology, Vol. 178, No.1, pp. 71-94, ISSN 0009-2541

Jia, Y. F.; Pang, J. L. \& Huang, C. C. (2004). pH value's measurement and research of its palaeoclimatic meaning in the Holocene loess section. Journal of Shaanxi Normal University (Natural Science Edition), Vol. 32, No. 2, pp. 102-105, ISSN 1672-4291

Langley-Turnbaugh, S. J. \& Bockheim, J. G. (1998). Mass balance of soil evolution on late Quaternary marine terraces in coastal Oregon. Geoderma, Vol. 84, No. 4, pp. 265-288, ISSN 0016-7061

Lichter, J. (1998). Rates of weathering and chemical depletion in soils across a chronosequence of Lake Michigan sand dunes. Geoderma, Vol. 85, No. 4, pp. 255282, ISSN 0016-7061

Liu, D. S. (2009). Loess and Arid Environment. Anhui Science and Technology Press, ISBN 978753-3743-10-9, Hefei, China

Maher, B. A.; Thompson, R. \& Zhou, L. P. (1994). Spatial and temporal reconstructions of changes in the Asian palaeomonsoon: A new mineral magnetic approach. Earth and Planetary Science Letters, Vol. 125, No. 1-4, pp. 461-471, ISSN 0012-821X

Manner, H. I. \& Morrison, R. J. (1991). A temporal sequence (chronosequence) of soil carbon and nitrogen development after phosphate mining on Nauru Island. Pacific Science, Vol. 45, No. 4, pp. 400-404, ISSN 0030-8870

Matthews, J. A. (1992). The Ecology of Recently-Deglaciated Terrain: A Geoecological Approach to Glacier Forelands and Primary Succession. Cambridge University Press, ISBN 978-0521361-09-5, Cambridge, UK.

Mellor, A. (1985). Soil chronosequences on Neoglacial moraine ridges, Jostedalsbreen and Jotunheimen, southern Norway: a quantitative pedogenic approach, In: Geomorphology and Soils, K. S. Richards, R. R. Arnett \& S. Ellis (Eds.), pp. 289-308. HarperCollins Publishers Ltd., ISBN 978-004-5510-93-1, London, UK

Mellor, A. (1987). A pedogenic investigation of some soil chronosequences on neoglacial moraine ridges, southern Norway: examination of soil chemical data using principal components analysis. Catena, Vol. 14, No. 5, pp. 369-381, ISSN 0341-8162

Merritts, D. J.; Chadwick, O. A. \& Hendricks, D. M. (1991). Rates and processes of soil evolution on uplifted marine terraces, northern California. Geoderma, Vol. 51, No. 14, pp. 241-275, ISSN 0016-7061

Miao, X. D.; Mason, J.; Goblet, R. J. \& Hanson, P. R. (2005). Loess record of dry climate and aeolian activity in the early-to mid-Holocene, central Great Plains, North America. The Holocene, Vol. 15, No. 3, pp. 339-346, ISSN 0959-6836 
Mook, W.G.\& Streurman, H.J. (1983). Physical and chemical aspects of radiocarbon dating. In: ${ }^{14} \mathrm{C}$ and Archaeology. Proceedings of the First International Symposium (=PACT 8), W.

G. Mook, \& H. T. Waterbolk, (Eds.), pp. 31 - 55. Strasbourg.

Morozova, T. D. (1990). Relict features of paleosols formed on loess and their age. Quaternary International, Vol. 7-8, pp. 29-35, ISSN 1040-6182

Muhs, D. R.; McGreehin, J. P.; Beann, J. \& Fisher, E. (2004). Holocene loess deposition and soil formation as competing processes, Matanuska Valley, southern Alaska. Quaternary Research, Vol. 61, No. 3, pp. 265-276, ISSN 0033-5894

Olson, J. S. (1958). Rates of succession and soil changes on Southern Lake, Michigan, sand dunes. Botanical Gazette, Vol. 119, No. 3, pp. 125-170, ISSN 0006-8071

Reimer, P. J.; Baillie, M. G. L.; Bard, E.; Bayliss, A.; Beck, J. W.; Bertrand, C. J. H.; Blackwell, P. G.; Buck, C. E.; Burr, G. S.; Cutler, K. B.; Damon, P. E.; Edwards, R. L.; Fairbanks, R. G.; Friedrich, M.; Guilderson, T. P.; Hogg, A. G.; Hughen, K. A.; Kromer, B.; McCormac, G.; Manning, S.; Bronk Ramsey, C.; Reimer, R. W.; Remmele, S.; Southon, J. R.; Stuiver, M.; Talamo, S.; Taylor, F. W.; Van der Plicht, J. \& Weyhenmeyer, C. E. (2004). IntCal04 terrestrial radiocarbon age calibration, 0-26 cal kyr BP. Radiocarbon, Vol. 46, No. 3, pp. 1029-1058, ISSN 0033-8222

Piccolo, M. C.; Neill, C. \& Cerri, C. C. (1994). Natural abundance of ${ }^{15} \mathrm{~N}$ in soils along forestto-pasture chronosequences in the western Brazilian Amazon Basin. Oecologia, Vol. 99, No. 1-2, pp. 112-117, ISSN 0029-8549

Sauer, D.; Schellmann, G. \& Stahr, K. (2007). A soil chronosequence in the semi-arid environment of Patagonia (Argentina). Catena, Vol. 71, No. 3, pp. 382-393, ISSN 0341-8162

Schaetzl, R. J.; Barrett, L. R. \& Winkler, J. A. (1994). Choosing models for soil chronofunctions and fitting them to data. European Journal of Soil Science, Vol. 45, No. 2, pp. 219-232, ISSN 1351-0754

Tang, K. L \& He, X. B. (2002). Revelation on genesis of multi paleosol from Quaternary loess profile. Acta Pedologica Sinica, Vol. 39, No. 5, pp. 609-617, ISSN 0564-3929

Tang, K. L. \& He, X. B. (2004). Re-discussion on loess-paleosol evolution and climatic change on the Loess Plateau during the Holocene. Quaternary Sciences, Vol. 24, No. 2, pp. 129-139, ISSN 1001-7410

Vincent, K. R.; Bull, W. B. \& Chadwick, O. A. (1994). Construction of a soil chronosequence using the thickness of pedogenic carbonate coatings. Journal of Geological Education, Vol. 42, 316-324, ISSN 0022-1368

Vogel, J. S.; Southon, J. R. \& Nelson, D. E. (1987). Catalyst and binder effects in the use of filamentous graphite for AMS. Nuclear Instruments and Methods in Physics Research Section B: Beam Interactions with Materials and Atoms, Vol. 29, No. 1-2, pp. 50-56. ISSN 0168-583X

Zarin, D. J. \& Johnson, A. H. (1995). Base saturation, nutrient cation, and organic matter increases during early pedogenesis on landslide scars in the Luquillo Experimental Forest, Puerto Rico. Geoderma, Vol. 65, No. 3-4, pp. 317-330, ISSN 0016-7061

Zhao, J. B.; Hao, Y. F. \& Yue, Y. L. (2006). Change of paleosol and climate during middle Holocene in Luochuan area of Shaanxi Province. Quaternary Science, Vol. 26, No. 6, pp. 969-975, ISSN 1001-7410

Zhu, X. M.; Li, Y. S.; Peng, X. L. \& Zhang, S. G. (1983). Soil of the loess region in China. Geoderma, Vol. 29, No. 3, pp. 237-255, ISSN 0016-7061 


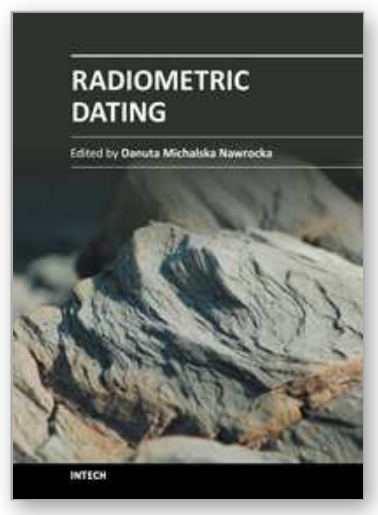

\author{
Radiometric Dating \\ Edited by Dr. Danuta Michalska Nawrocka
}

ISBN 978-953-51-0596-1

Hard cover, 126 pages

Publisher InTech

Published online 09, May, 2012

Published in print edition May, 2012

This book explores a diversity of topics related to radiometric dating, with particular emphasis on the method of radiocarbon dating and a cross-check of its results with luminescence measurements. Starting from the chapter on Methodology the book includes, among other topics, the description of the problem of preparation of samples for $14 \mathrm{C}$ measurement, a wide application of the radiocarbon method and a comparison of results obtained by various methods, including the radiocarbon method, the method of OSL, TL and palynology. The issue of radiocarbon dating of mortars and plasters is thoroughly discussed in the book. Chapter Two, Applications, and Three, Luminescence and Radiocarbon Measurements, provide examples of the application of the radiocarbon method in the study of archaeological, geological sites, from the analysis of soils, loesses, to the study of organic deposits filling the depressions in the Morasko Meteorite Nature Reserve. A wide range of studies reveals the great potential of the radiocarbon method, and the presented papers reflect interdisciplinary research.

\title{
How to reference
}

In order to correctly reference this scholarly work, feel free to copy and paste the following:

Gang Liu, Wennian Xu, Qiong Zhang and Zhenyao Xia (2012). Holocene Soil Chronofunctions, Luochuan, Chinese Loess Plateau, Radiometric Dating, Dr. Danuta Michalska Nawrocka (Ed.), ISBN: 978-953-51-0596-1, InTech, Available from: http://www.intechopen.com/books/radiometric-dating/holocene-soil-chronofunctionsluochuan-chinese-loess-plateau

\section{INTECH}

open science | open minds

\section{InTech Europe}

University Campus STeP Ri

Slavka Krautzeka 83/A

51000 Rijeka, Croatia

Phone: +385 (51) 770447

Fax: +385 (51) 686166

www.intechopen.com

\section{InTech China}

Unit 405, Office Block, Hotel Equatorial Shanghai

No.65, Yan An Road (West), Shanghai, 200040, China

中国上海市延安西路65号上海国际贵都大饭店办公楼405单元

Phone: +86-21-62489820

Fax: $+86-21-62489821$ 
(C) 2012 The Author(s). Licensee IntechOpen. This is an open access article distributed under the terms of the Creative Commons Attribution 3.0 License, which permits unrestricted use, distribution, and reproduction in any medium, provided the original work is properly cited. 